\title{
Fatigue Testing of Abrasive Water Jet Cut Titanium
}

\author{
YH Hovanski RE Williford \\ ME Dahl
}

June 2009

\section{Pacific Northwest}

NATIONAL LABORATORY 


\title{
DISCLAIMER
}

This report was prepared as an account of work sponsored by an agency of the United States Government. Neither the United States Government nor any agency thereof, nor Battelle Memorial Institute, nor any of their employees, makes any warranty, express or implied, or assumes any legal liability or responsibility for the accuracy, completeness, or usefulness of any information, apparatus, product, or process disclosed, or represents that its use would not infringe privately owned rights. Reference herein to any specific commercial product, process, or service by trade name, trademark, manufacturer, or otherwise does not necessarily constitute or imply its endorsement, recommendation, or favoring by the United States Government or any agency thereof, or Battelle Memorial Institute. The views and opinions of authors expressed herein do not necessarily state or reflect those of the United States Government or any agency thereof.

\author{
PACIFIC NORTHWEST NATIONAL LABORATORY \\ operated by \\ BATTELLE \\ for the \\ UNITED STATES DEPARTMENT OF ENERGY \\ under Contract DE-AC05-76RL01830
}

Printed in the United States of America

Available to DOE and DOE contractors from the

Office of Scientific and Technical Information,

P.O. Box 62, Oak Ridge, TN 37831-0062;

ph: (865) 576-8401

fax: $(865) 576-5728$

email: reports@adonis.osti.gov

\footnotetext{
Available to the public from the National Technical Information Service, U.S. Department of Commerce, 5285 Port Royal Rd., Springfield, VA 22161 ph: (800) 553-6847 fax: $(703) 605-6900$

email: orders@ntis.fedworld.gov

online ordering: http://www.ntis.gov/ordering.htm
}

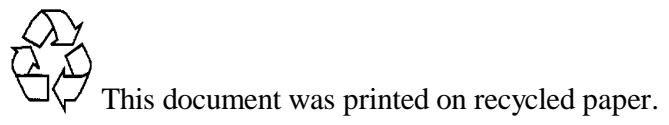




\title{
Fatigue Testing of Abrasive Water Jet Cut Titanium
}

\author{
YH Hovanski \\ RE Williford
}

ME Dahl

June 2009

Prepared for

the OMAX Corporation

Kent, Washington

under Contract DE-AC05-76RL01830

TAP Agreement 09-02

Pacific Northwest National Laboratory

Richland, Washington 99352 



\section{Summary}

Battelle Memorial Institute, under U.S. Department of Energy Contract No. DE-AC05-76RL01830 to operate the Pacific Northwest National Laboratory, agreed to provide technology services to the OMAX Corporation in accordance with Technology Assistance Program Agreement number 09-02. This agreement was designed to provide assistance to the OMAX Corporation in performing fatigue analysis of several aerospace titanium alloys that were prepared using abrasive water-jet technologies. Fatigue specimens and test conditions were provided by the OMAX Corporation, and testing and characterization were performed at the Pacific Northwest National Laboratory. 



\section{Acronyms and Abbreviations}

AWJ

PNNL

USDOE

TAP

Q1

Q3

Q5

KSI

KIP
Abrasive Water Jet

Pacific Northwest National Laboratory

United States Department of Energy

Technology Assistance Program

Quality Level 1 Surface Preparation, Lowest Quality

Quality Level 3 Surface Preparation, Medium Quality

Quality Level 5 Surface Preparation, Highest Quality

Thousand pounds per square inch

Thousand pounds 



\section{Contents}

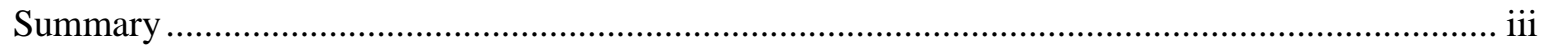

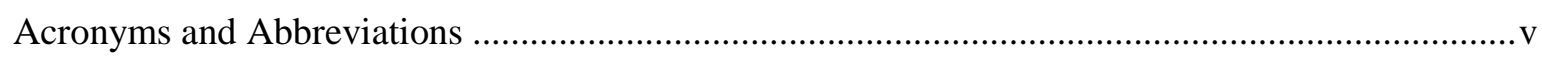

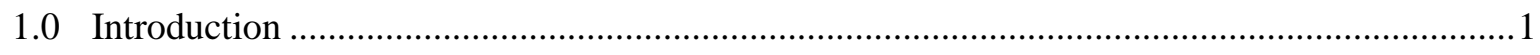

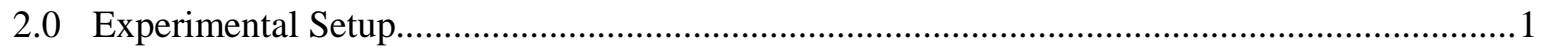

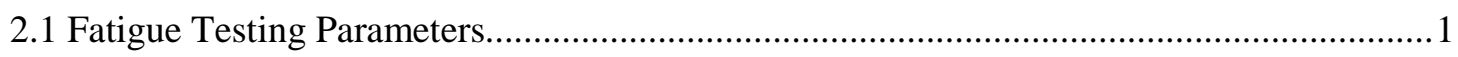

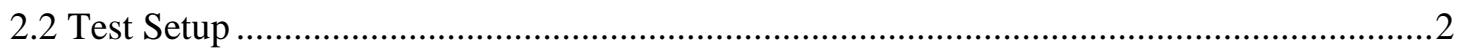

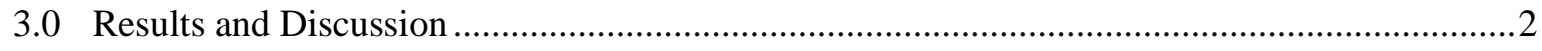

3.1 Baseline Machined Specimen Characterization .............................................................2

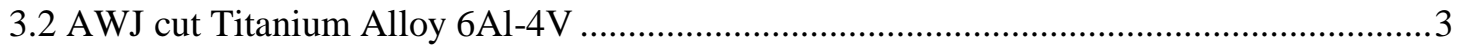

3.3 Effects of Grit Blasting of AWJ Cut Titanium Fatigue Specimens .....................................9

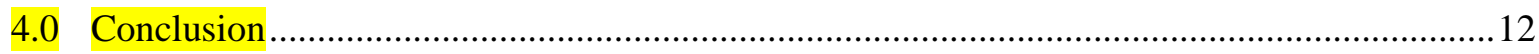

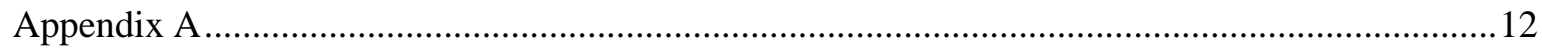

\section{Figures}

Figure 1. As Tested Titanium Fatigue Specimen Prepared Via Machining...................................3

Figure 2. Titanium fatigue specimens abrasively water jut cut to Q1 using 80 mesh grit................5

Figure 3. Titanium fatigue specimens abrasively water jut cut to Q1 using 220 mesh grit...............5

Figure 4. Titanium fatigue specimens abrasively water jut cut to Q3 using 80 mesh grit.................6

Figure 5. Titanium fatigue specimens abrasively water jut cut to Q3 using 220 mesh grit...............6

Figure 6. Titanium fatigue specimens abrasively water jut cut to Q5 using 80 mesh grit.................7

Figure 7. Titanium fatigue specimens abrasively water jut cut to Q5 using 220 mesh grit................8

Figure 8. Titanium fatigue specimens abrasively water jut cut to Q5 using 320 mesh grit...............8

\section{Tables}

Table 1. Fatigue Data for Baseline Machined Fatigue Specimen in Ti-6-4 ...................................2

Table 2. Fatigue Data for Abrasive Water Jet Cut Titanium Specimens. .........................................4 



\subsection{Introduction}

Battelle Memorial Institute as part of its U.S. Department of Energy (USDOE) Contract No. DEAC05-76RL01830 to operate the Pacific Northwest National Laboratory (PNNL) provides technology assistance to qualifying small businesses in association with a Technology Assistance Program (TAP). Qualifying companies are eligible to receive a set quantity of labor associated with specific technical assistance. Having applied for a TAP agreement to assist with fatigue characterization of Abrasive Water Jet (AWJ) cut titanium specimens, the OMAX Corporation was awarded TAP agreement 09-02. This program was specified to cover dynamic testing and analysis of fatigue specimens cut from titanium alloy Ti-6\%Al-4\%V via AWJ technologies. In association with the TAP agreement, a best effort agreement was made to characterize fatigue specimens based on test conditions supplied by OMAX.

Testing parameters supplied to PNNL required dynamic loading in the reduced gage cross-section to reach an upper stress limit of 70,000 psi. An R-value of -0.02 was specified, leading to control of the compressive load to $2 \%$ of the maximum tensile value. A testing rate was specified at 10 hertz, with an upper testing limit of one million cycles. Cross-sectional areas were measured for each specimen at the reduced gage, and variation in surface conditions over sample sets was visually documented.

\subsection{Experimental Setup}

Fatigue testing was performed in accordance with ASTM standards E466-96 and E468-90. Specimens were prepared per section 5.2.2.2 of E466, providing a continuous radius between ends of a rectangular cross section.

\subsection{Fatigue Testing Parameters}

In accordance with TAP agreement 09-02, the OMAX Corporation provided PNNL with specific test parameters appropriate for the titanium fatigue specimens provided. These parameters were based in specified guidelines in applicable ASTM standards, and required a maximum axial stress limit of 70,000 psi at the reduced gage section. As such each specimen was measured in thickness and width using a standard digital dial caliper to five significant figures. The minimum cross-sectional area of the reduced gage section was determined using these measurements, and an appropriate load was selected to reach to the $70 \mathrm{KSI}$ limit. An R-value of -0.02 was specified for all testing, providing a ratio of minimum to maximum stress that provided both tension and compression. Values for the associated minimum and maximum loads are given in Tables (1-3).

While the cyclical loading rate was specified at 10 hertz, the specified loading conditions only allowed for a practical upper frequency of 7.5 hertz. At frequencies above 7.5, the internal natural frequency of the system was too close to that of the tested specimen, which led to unstable performance.

Upper and lower cyclical bounds were designed to be one million and thirty thousand, respectively. Failure was categorized as complete fracture or a crack of at least 0.012 inches. Specimen testing order was originally provided by the OMAX Corporation and was modified throughout the duration of the 
testing to better accommodate the specific goals of Dr. Peter Liu, senior researcher at the OMAX Corporation.

\subsection{Test Setup}

All testing was performed at ambient room temperature using constant amplitude loading. Standard lab practices were used for testing all fatigue specimens. Alignment of each test specimen was set and checked using mechanical stops against the hydraulic grips. Grip pressure was set at 2800 psi. Limits were set on the digital controller to protect the sample during loading and to detect fractures in the sample. The constant amplitude sine wave was observed on an oscilloscope during testing as a secondary verification of the load values that were set and displayed on the digital controller. The load cell in the test frame was verified prior to testing and post testing against a calibrated load cell. The test system used in this study was a MTS 50 Kip servo hydraulic test frame MTS model 312.31 that was controlled with an Instron 8800 digital controller. The load cell was a MTS 25 metric ton model 661.23A.01. The wedge action grips were MTS model 647 and were controlled with a MTS model 585.60 grip supply.

\subsection{Results and Discussion}

Assessment of the fatigue performance of specimens cut from aerospace titanium was designed to compare the performance of AWJ cut specimens to a more traditional baseline process like machining. A preliminary look at the surface roughness of the machined specimens allowed for comparison of the AWJ properties. Samples with varying surface roughness were prepared via AWJ, and were specified by quality levels one through five, with one being the roughest and five been the smoothest. A complete list of test specimens including quantification of the surface properties and quality levels is included in Appendix A.

\subsection{Baseline Machined Specimen Characterization}

An investigation of standard machined specimens was undertaken to characterize a baseline performance of titanium fatigue specimens used in this study. Only a single specimen of the four provided was tested as part of TAP 09-02. Details related to the test are presented in Table 1, with the individual tested specimen shown in Figure 1.

Table 1. Fatigue Data for Baseline Machined Fatigue Specimen in Ti-6-4.

\begin{tabular}{|l|l|l|l|l|l|l|r|r|l|}
\hline Sample ID & Date & Thickness & Width & $\begin{array}{l}\text { max } \\
\text { load } \\
\text { kips }\end{array}$ & $\begin{array}{l}\text { MIN } \\
\text { LOAD } \\
\text { kips }\end{array}$ & $\begin{array}{l}\text { SETPOINT } \\
\text { kips }\end{array}$ & AMPLITUDE & Ksi & $\begin{array}{l}\text { cycles } \\
\text { to } \\
\text { failure }\end{array}$ \\
\hline & & & & 0.0 & 0.00 & 0.00 & 0.00 & & \\
\hline TiMS125-1 & $3 / 12 / 2009$ & 0.12745 & 1.8410 & 16.4 & -0.33 & 8.05 & 8.38 & 70 & 348,057 \\
\hline
\end{tabular}




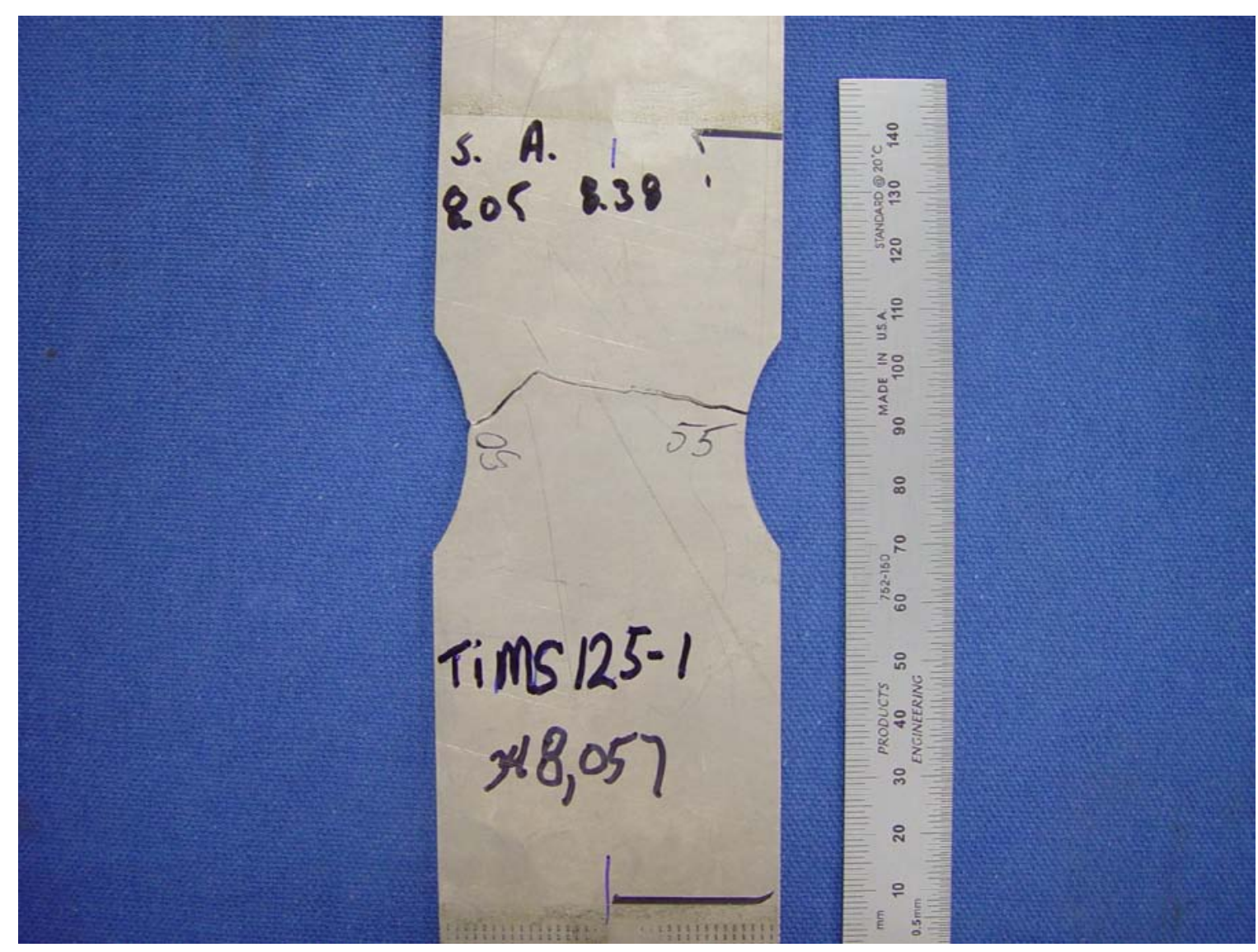

Figure 1. As Tested Titanium Fatigue Specimen Prepared Via Machining.

\subsection{AWJ cut Titanium Alloy 6Al-4V}

After initial testing of the machined specimens, groups of test specimens from each AWJ cut condition were tested. Table 2 shows the experimental details and fatigue life cycle for titanium specimens ranging from Quality Level 1 (Q1) through Quality Level 5 (Q5). Figures 2-7 show groups of fatigue specimens sorted based on quality level and grit size.

Figures 2 and 3 show titanium, fatigue specimens that were prepared using an AWJ to Q1 using 80 mesh and 220 mesh grit respectively. Decreasing the grit size for the higher mesh abrasive seemed to only increase the overall surface roughness for samples cut to Q1 and Q3. Quality level 1 samples shown in Figure 2 had an average surface roughness of $\mathrm{Ra}=12.70$ while specimens cut with a finer grit (higher mesh) showed an average surface roughness of $\mathrm{Ra}=14.54$. 
Table 2. Fatigue Data for Abrasive Water Jet Cut Titanium Specimens.

\begin{tabular}{|c|c|c|c|c|c|c|c|c|c|}
\hline Sample ID & Date & Thickness & Width & $\begin{array}{l}\max \\
\text { load } \\
\text { kips }\end{array}$ & \begin{tabular}{|l|} 
MIN \\
LOAD \\
kips
\end{tabular} & $\begin{array}{l}\text { SETPOINT } \\
\text { kips }\end{array}$ & AMPLITUDE & Ksi & $\begin{array}{l}\text { cycles } \\
\text { to } \\
\text { failure }\end{array}$ \\
\hline & & & & $\begin{array}{l}0.0 \\
\end{array}$ & 0.00 & 0.00 & \begin{tabular}{r|}
0.00 \\
\end{tabular} & & \\
\hline TiAQ180-1 & $12 / 19 / 2008$ & 0.13040 & 1.8080 & 16.5 & -0.33 & 8.09 & 8.42 & 70 & 25,119 \\
\hline TiAQ180-2 & $12 / 19 / 2008$ & 0.13030 & 1.8050 & 16.5 & -0.33 & 8.07 & 8.40 & 70 & 35,047 \\
\hline TiAQ180-3 & $12 / 22 / 2008$ & 0.13040 & 1.8045 & 16.5 & -0.33 & 8.07 & 8.40 & 70 & 22,899 \\
\hline \multirow[t]{2}{*}{ TiAQ180-4 } & & & & 0.0 & 0.00 & 0.00 & 0.00 & & \\
\hline & & & & 0.0 & 0.00 & 0.00 & 0.00 & & \\
\hline TiAQ380-1 & $11 / 10 / 2008$ & 0.12920 & 1.8025 & 16.3 & -0.33 & 7.99 & 8.31 & 70 & 51,432 \\
\hline TiAQ380-2 & $12 / 1 / 2008$ & 0.12925 & 1.8015 & 16.3 & -0.33 & 7.99 & 8.31 & 70 & 55,988 \\
\hline TiAQ380-3 & $12 / 10 / 2008$ & 0.12900 & 1.8020 & 16.3 & -0.33 & 7.97 & 8.30 & 70 & 62,631 \\
\hline \multirow[t]{2}{*}{ TiAQ380-4 } & & & & 0.0 & 0.00 & 0.00 & 0.00 & 70 & \\
\hline & & & & 0.0 & 0.00 & 0.00 & 0.00 & & \\
\hline TiAQ580-1 & $11 / 19 / 2008$ & 0.12870 & 1.8005 & 16.2 & -0.32 & 7.95 & 8.27 & 70 & 50,930 \\
\hline TiAQ580-2 & $12 / 3 / 2008$ & 0.12870 & 1.8000 & 16.2 & -0.32 & 7.95 & 8.27 & 70 & 50,337 \\
\hline TiAQ580-3 & $12 / 15 / 2008$ & 0.12865 & 1.7950 & 16.2 & -0.32 & 7.92 & 8.24 & 70 & 63,336 \\
\hline \multirow[t]{2}{*}{ TiAQ580-4 } & & & & 0.0 & 0.00 & 0.00 & 0.00 & 70 & \\
\hline & & & & 0.0 & 0.00 & 0.00 & 0.00 & & \\
\hline TiAQ1220-1 & $11 / 19 / 2008$ & 0.12715 & 1.8065 & 16.1 & -0.32 & 7.88 & 8.20 & 70 & 22,160 \\
\hline TiAQ1220-2 & $12 / 2 / 2008$ & 0.12730 & 1.8055 & 16.1 & -0.32 & 7.88 & 8.21 & 70 & 11,593 \\
\hline TiAQ1220-3 & $12 / 10 / 2008$ & 0.12760 & 1.8035 & 16.1 & -0.32 & 7.89 & 8.22 & 70 & 17,715 \\
\hline \multirow[t]{2}{*}{ TiAQ1220-4 } & & & & 0.0 & 0.00 & 0.00 & 0.00 & 70 & \\
\hline & & & & 0.0 & 0.00 & 0.00 & 0.00 & & \\
\hline TiAQ3220-1 & $11 / 10 / 2008$ & 0.12750 & 1.8020 & 16.1 & -0.32 & 7.88 & 8.20 & 70 & 27,512 \\
\hline TiAQ3220-2 & $12 / 10 / 2008$ & 0.12750 & 1.8025 & 16.1 & -0.32 & 7.88 & 8.20 & 70 & 26,561 \\
\hline TiAQ3220-3 & $12 / 16 / 2008$ & 0.12750 & 1.8015 & 16.1 & -0.32 & 7.88 & 8.20 & 70 & 36,640 \\
\hline \multirow[t]{2}{*}{ TiAQ3220-4 } & & & & 0.0 & 0.00 & 0.00 & 0.00 & 70 & \\
\hline & & & & 0.0 & 0.00 & 0.00 & 0.00 & 70 & \\
\hline TiAQ5220-1 & $11 / 18 / 2008$ & 0.12515 & 1.8000 & 15.8 & -0.32 & 7.73 & 8.04 & 70 & 39,924 \\
\hline TiAQ5220-2 & $12 / 9 / 2008$ & 0.12510 & 1.8000 & 15.8 & -0.32 & 7.72 & 8.04 & 70 & 69,731 \\
\hline TiAQ5220-3 & $12 / 17 / 2008$ & 0.12530 & 1.8000 & 15.8 & -0.32 & 7.74 & 8.05 & 70 & 56,233 \\
\hline \multirow[t]{2}{*}{ TiAQ5220-4 } & & & & 0.0 & 0.00 & 0.00 & 0.00 & 70 & \\
\hline & & & & 0.0 & 0.00 & 0.00 & 0.00 & & \\
\hline TiAQ5320-1 & $12 / 19 / 2008$ & 0.1281 & 1.7995 & 16.1 & -0.32 & 7.91 & 8.23 & 70 & 47890 \\
\hline TiAQ5320-2 & $12 / 19 / 2008$ & 0.1281 & 1.7995 & 16.1 & -0.32 & 7.91 & 8.23 & 70 & 55766 \\
\hline TiAQ5320-2 set 2 & $12 / 22 / 2008$ & 0.1269 & 1.797 & 16.0 & -0.32 & 7.82 & 8.14 & 70 & 62397 \\
\hline TiAQ5320-3 & & & & 0.0 & 0.00 & 0.00 & 0.00 & 70 & \\
\hline TiAQ5320-4 & & & & 0.0 & 0.00 & 0.00 & 0.00 & $70 \mid$ & \\
\hline
\end{tabular}




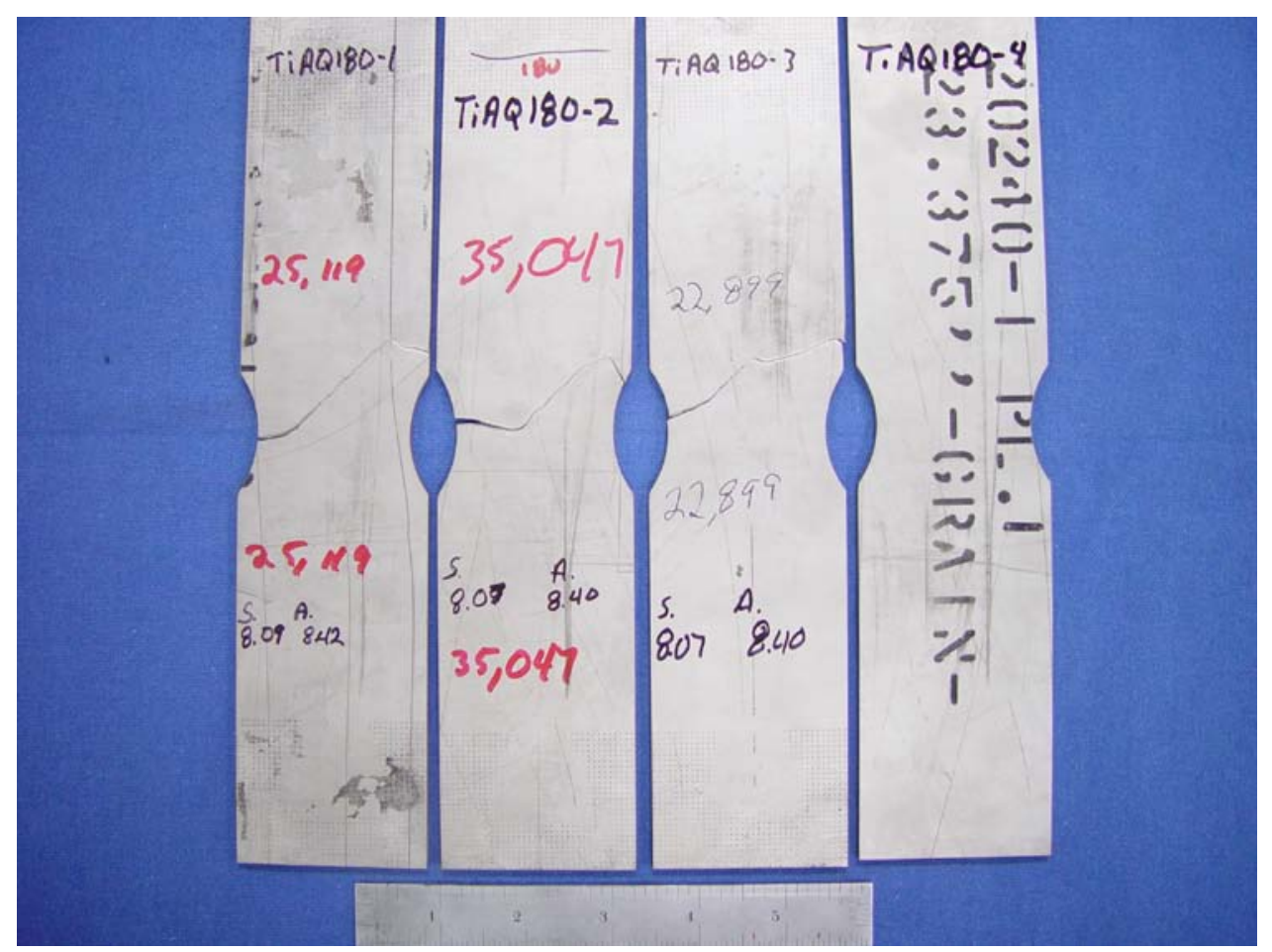

Figure 2. Titanium fatigue specimens abrasively water jut cut to Q1 using 80 mesh grit.

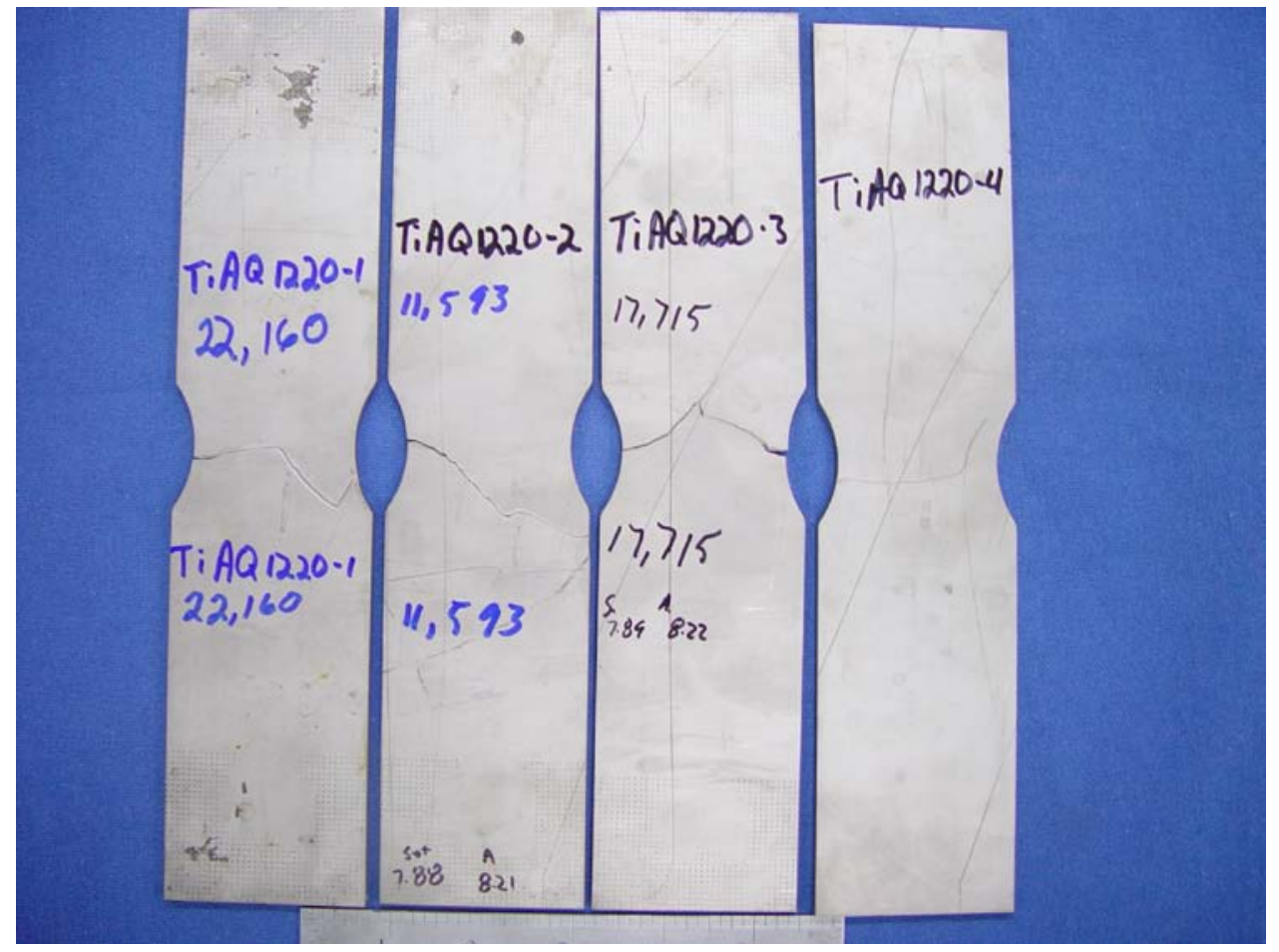

Figure 3. Titanium fatigue specimens abrasively water jut cut to Q1 using 220 mesh grit. 
Figures 4 and 5 show titanium, fatigue specimens that were prepared using an AWJ to Q3 using 80 mesh and 220 mesh grit respectively. As with the Q1 specimens decreasing the grit size for the higher mesh abrasive seemed to only increase the overall surface roughness. Quality level 3 samples shown in Figure 4 had an average surface roughness of $\mathrm{Ra}=6.78$ while specimens cut with a finer grit (higher mesh) showed an average surface roughness of $\mathrm{Ra}=8.20$.

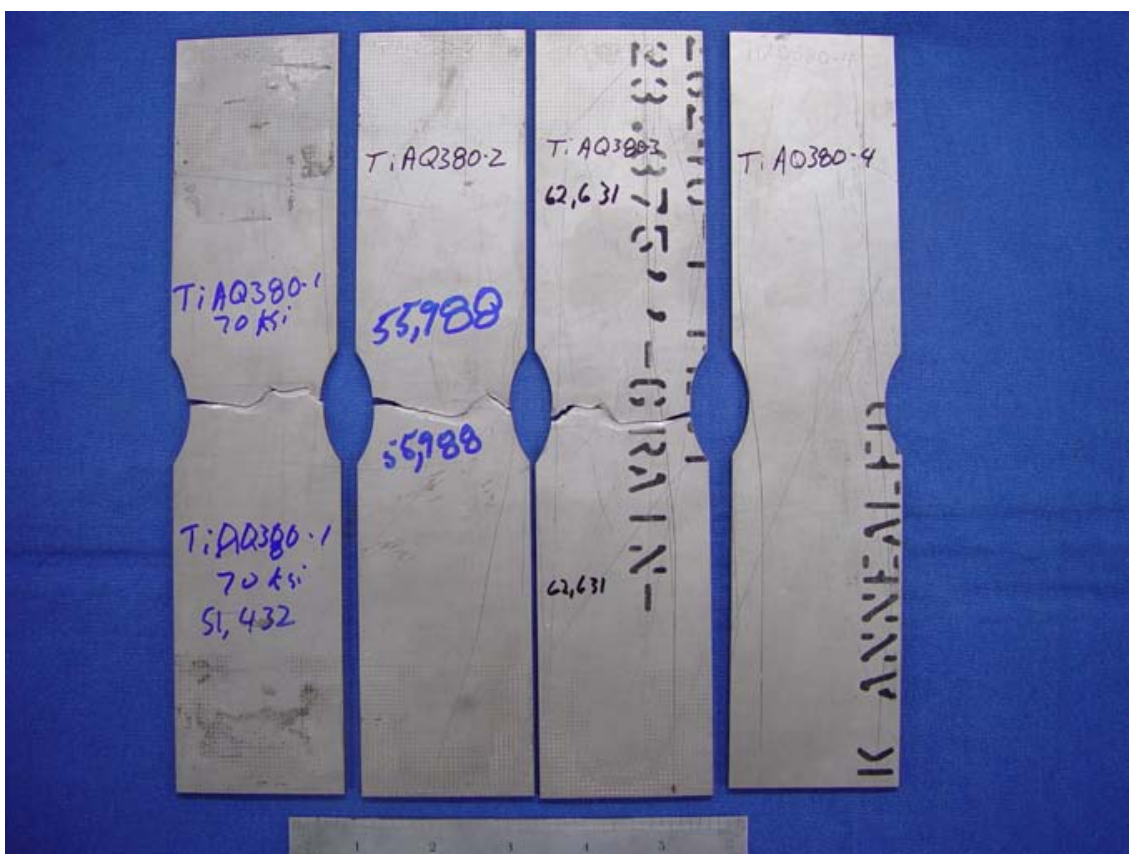

Figure 4. Titanium fatigue specimens abrasively water jut cut to Q3 using 80 mesh grit.

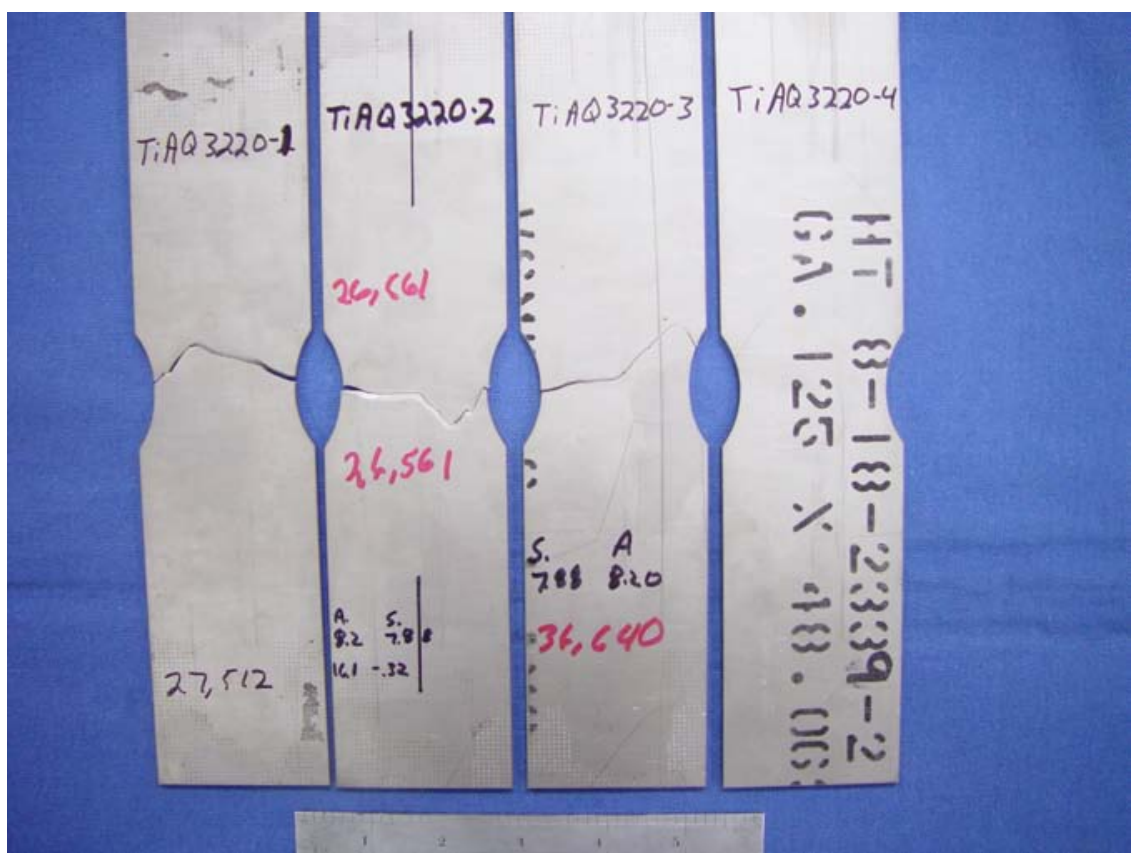

Figure 5. Titanium fatigue specimens abrasively water jut cut to Q3 using 220 mesh grit. 
Figures 6, 7 and 8 show titanium, fatigue specimens that were prepared using an AWJ to Q5 using 80, 220, and 320 mesh grit respectively. Unlike the Q1 and Q3 specimens, decreasing the grit size to a higher mesh abrasive seemed to directly improve (decrease) the overall surface roughness. Quality level 1 samples shown in Figure 6 had an average surface roughness of $\mathrm{Ra}=4.94$ while specimens cut with a finer grit (higher mesh) showed an average surface roughness of $\mathrm{Ra}=3.24$ and 2.76.

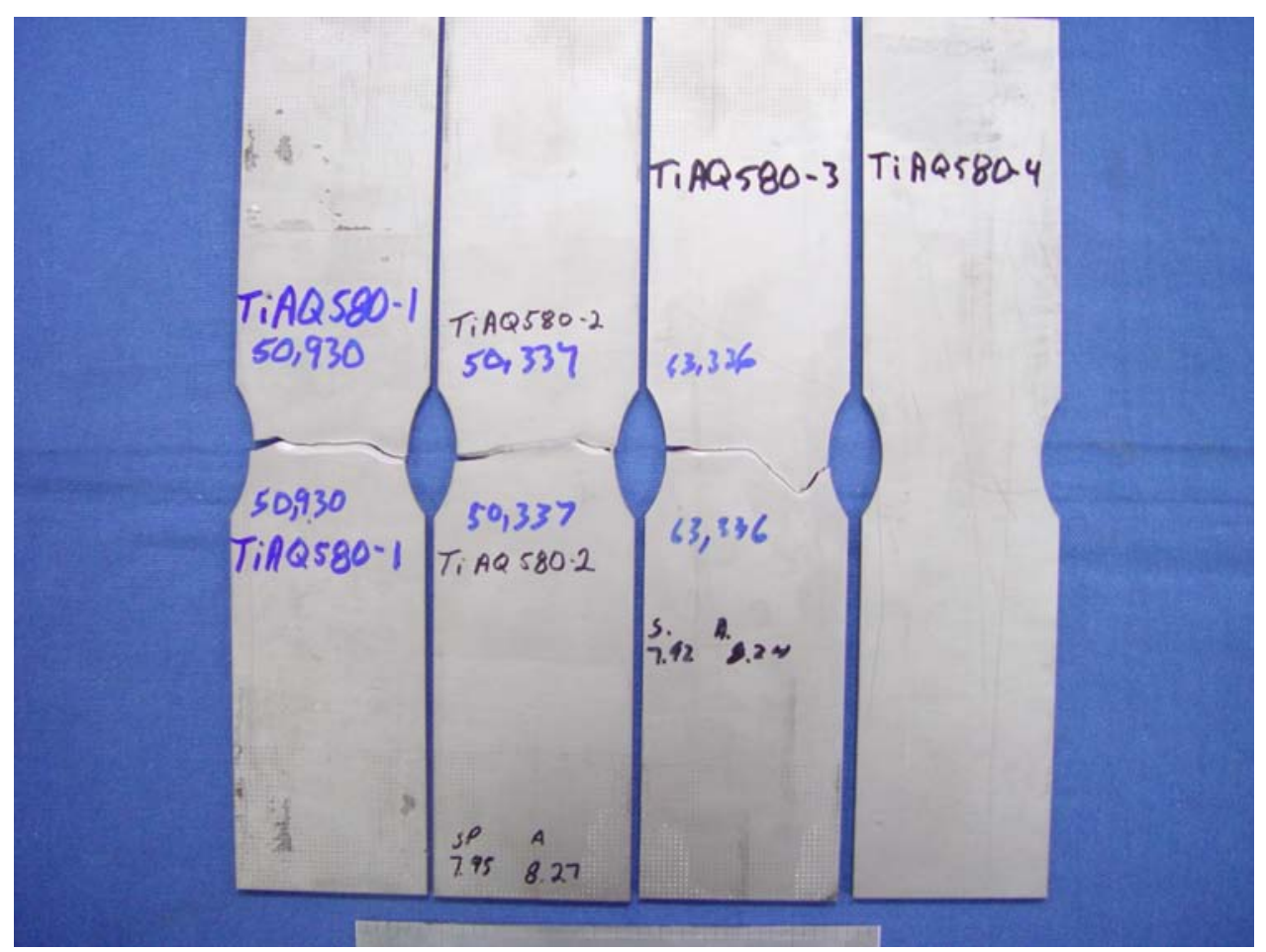

Figure 6. Titanium fatigue specimens abrasively water jut cut to Q5 using 80 mesh grit. 


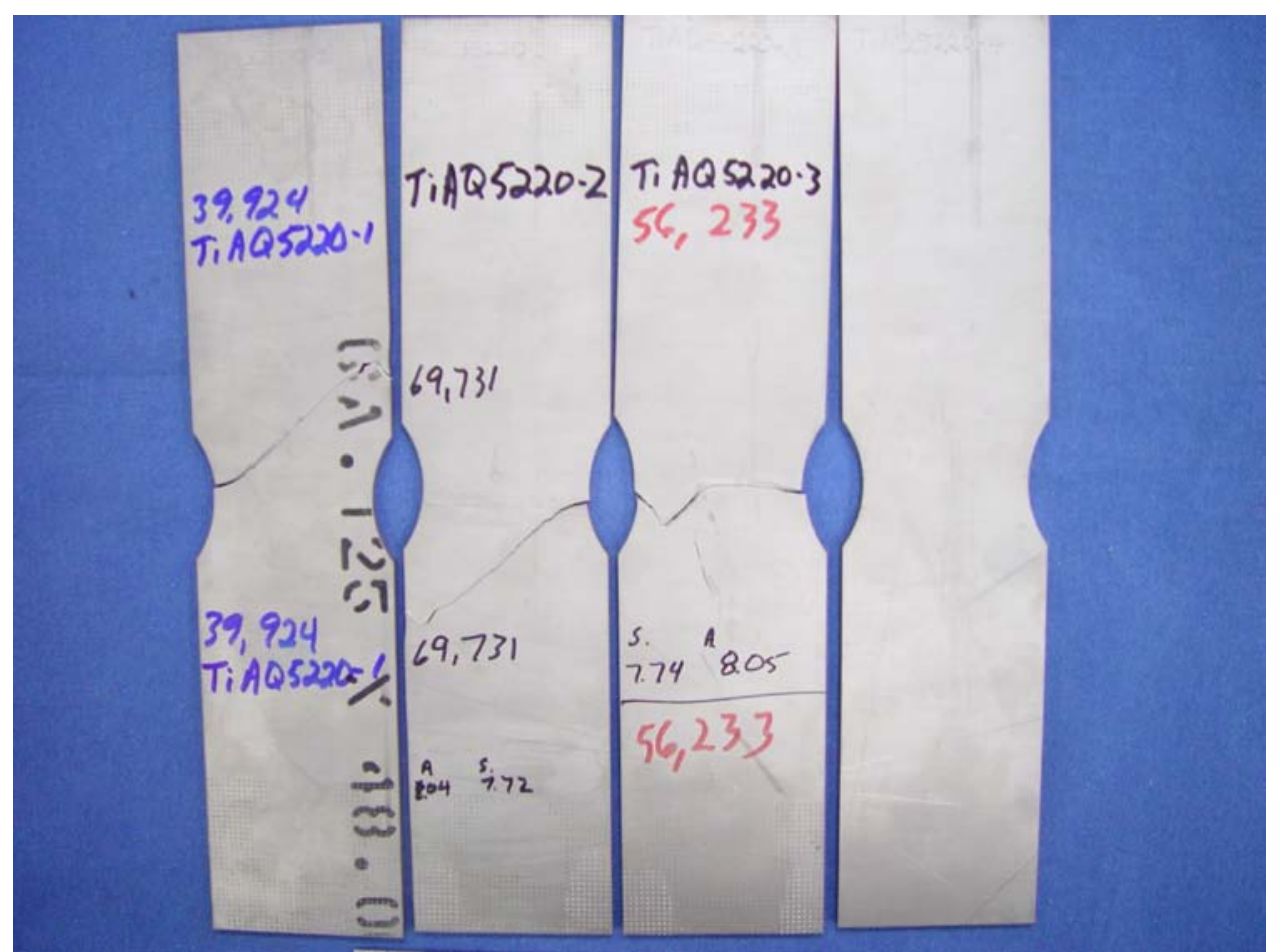

Figure 7. Titanium fatigue specimens abrasively water jut cut to Q5 using 220 mesh grit.

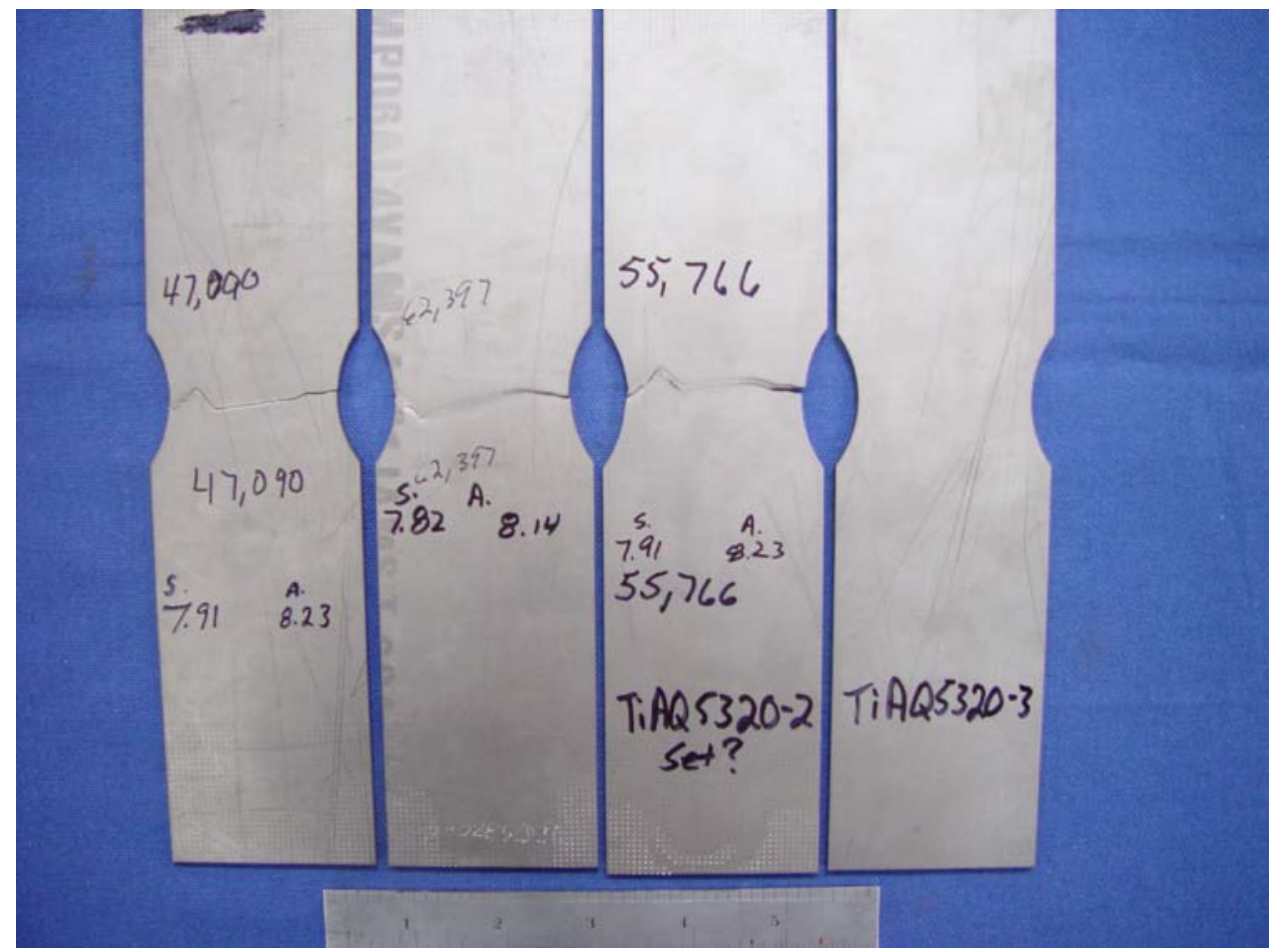

Figure 8. Titanium fatigue specimens abrasively water jut cut to Q5 using 320 mesh grit. 


\subsection{Effects of Grit Blasting of AWJ Cut Titanium Fatigue Specimens}

The influence of quality level in AWJ cut fatigue samples is quite apparent when examining the performance of quality level 1 and 5 specimens prepared using 220 and 80 grit abrasives. Improvement in quality level conclusively led to an increase in fatigue life regardless of the mesh size of the grit. While the improvement in fatigue life based on quality level was more dramatic in the 80 mesh case, all conditions tested herein showed that improvements beyond Q1 increased the fatigue life.

While percentage based improvements were noticed by enhancements made in the surface roughness and quality level of the AWJ cut surfaces, a more significant effect (order of magnitude scale) was realized by implementation of grit blasting the as cut reduced section of the titanium fatigue specimens. Figure 9 shows Q4 and Q5 samples that have been cut using 120 and 220 mesh respectively. This figure also displays the baseline sample (as machined) and a machined and sanded sample (TiAS125-1).

Samples TiMS125-1 and TiAQ4120G-2 both failed in the grip, at which point phenolic grip inserts were used to reduced the stress concentrations in the grip area. With the use of phenolic inserts both the assanded and TiAQ4120G-2 were cycled to run out (1,000,000 cycles), while the others failed as noted.

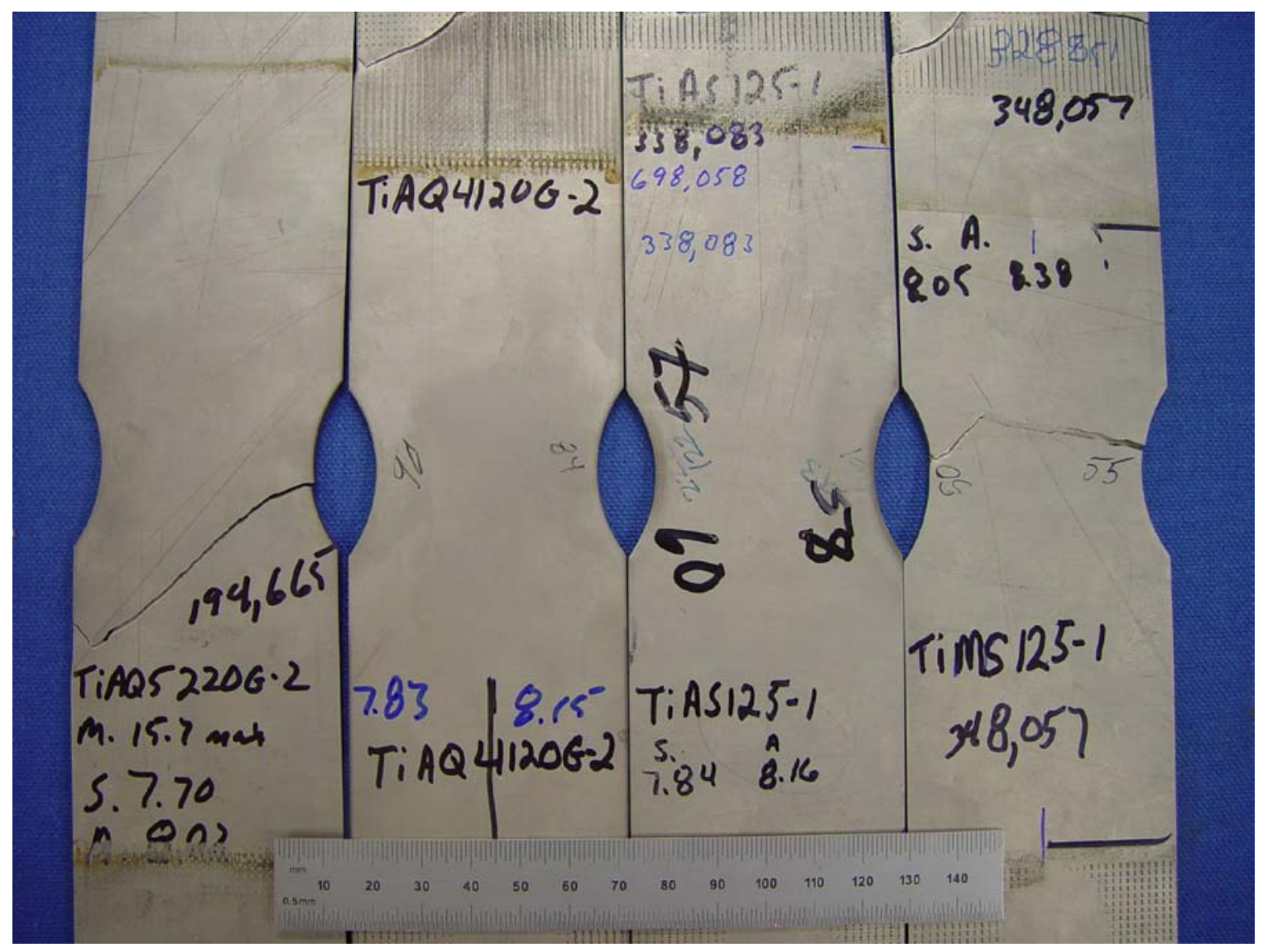

Figure 9. Titanium fatigue specimens cut via AWJ and grit blasted (left two) compared with those cut via traditional machining. 


\subsection{Edge Characterization Using Atomic Force Microscopy}

As a follow-up to previous characterization done to analyze the influence of cutting technologies on the material properties of the near edge in titanium metals, a portion of TAP 09-02 was allotted to further characterize titanium sheet that had been cut via laser. This task was undertaken as a means of comparing previously acquired data that investigated the surface conditions of titanium metals that had been cut using AWJ and wire EDM methods. Data were obtained using a Hysitron Picoindenter mounted on a Veeco Digital Instruments Nanoscope III Atomic Force Microscope, and were used for comparison of surface hardnesses over the first 30 microns from the edge.

Figure 10 shows the that most persistent feature was the peak that occurs at about 12.5 microns from the apparent edge (at $x=0$ in the plot). Note that successive runs on a sample are often at different distances from the edge, due to edge roughness. So the curves from the runs were shifted so that the peak was coincident, using run 3 of sample 1 as the reference. The physical significance of the peak is uncertain, but could be associated with, e.g., residual stresses or surface oxidation.

To the left of the peak is a softer region nearest the edge. Note that the hardness values may be affected by the rounded edge geometry in this region. However, it is also physically reasonable that the heat from the laser cutting has annealed the first 10-12 microns of Ti nearest the cut edge.

To the right of the peak a difference in samples is apparent, with sample 1 exhibiting noticeably larger hardness than sample 2 . This is representative of the difficulties associated with the surface texture and roughness of the samples. Future experiments should be metallographically polished.

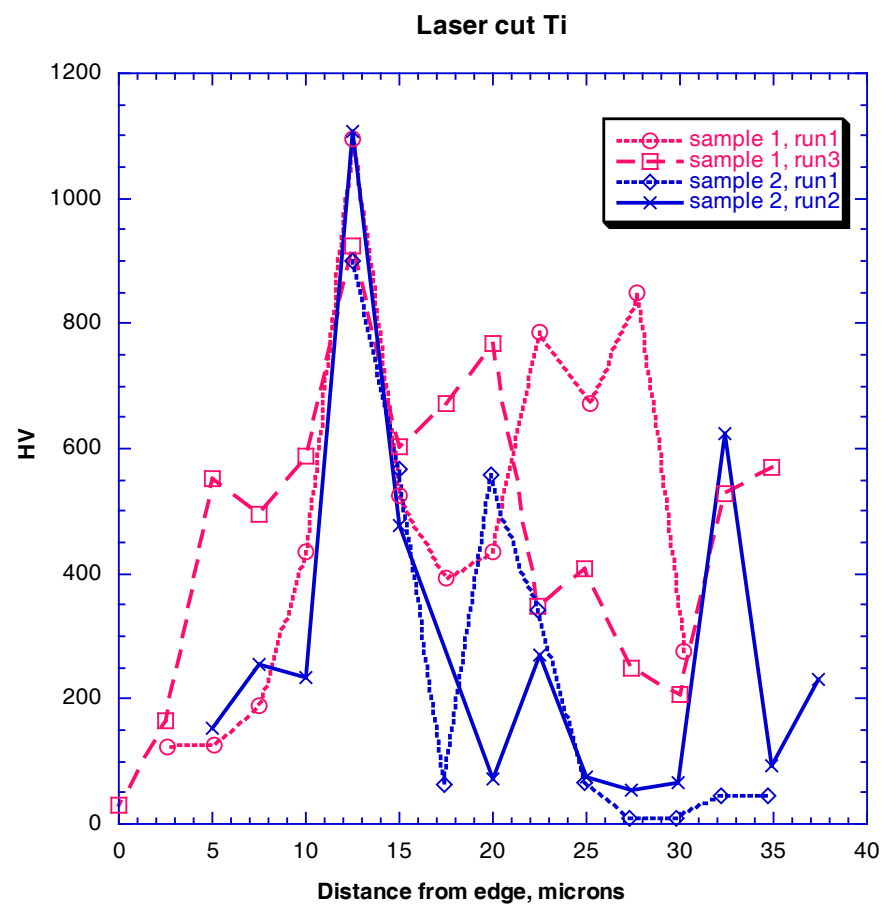

Figure 10. Nano-indentation near the cut edge of the laser cut Ti plate sample.

Hardness values of the titanium sheet cut via laser were problematic as noise due to surface roughness was of the same scale as the base hardness. Figures 11 and 12 show comparative charts that relate 
effective surface hardness of titanium metal cut using each of the three technologies characterized for the OMAX Corporation.

Because the laser-cut specimen had not been metallographically polished prior to performing nanoindentation, there was some suspect data at the near surface. As such Figures 11 and 12 demonstrate the differences of shifting the data based on slight surface imperfections in the first 15 microns.

Unfortunately the geometry of the cut edge is too complex to enable definitive identification of the exact edge location with the indenter instrument.

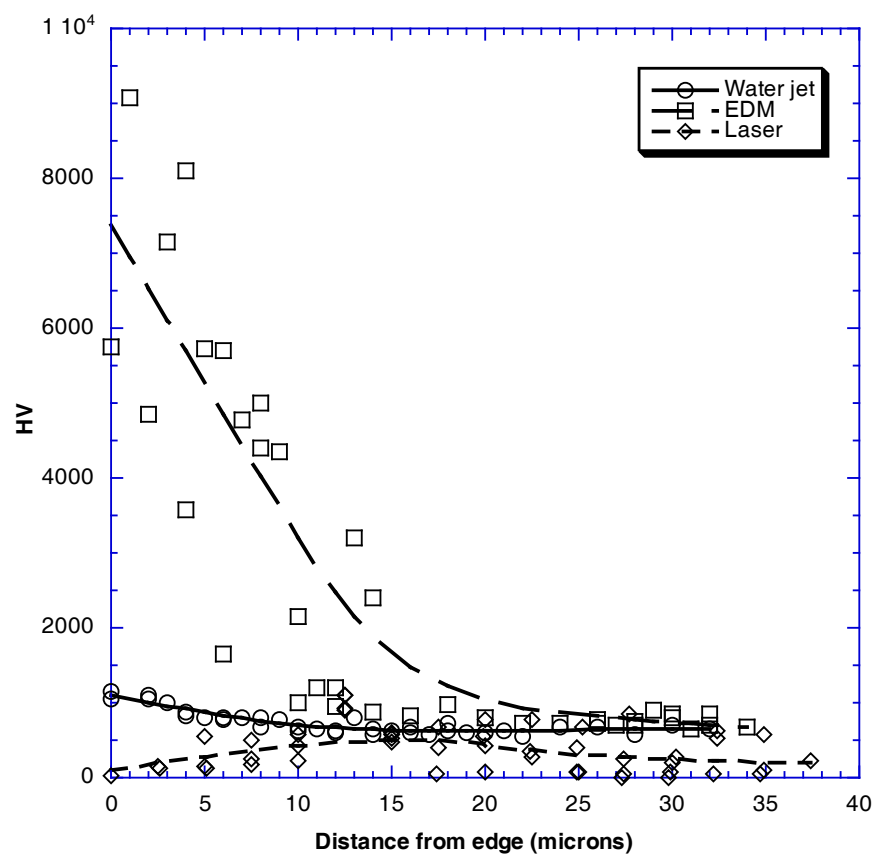

Figure 11. Laser cut sample is not shifted. 


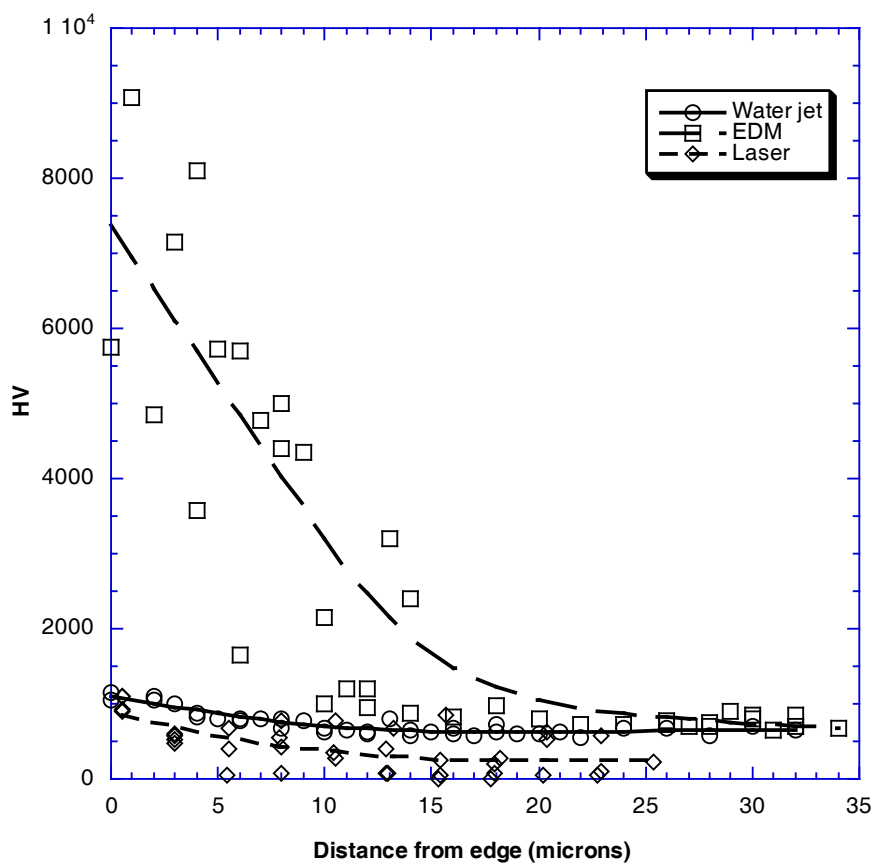

Figure 12. Laser cut sample is shifted left by 12 microns, so that the peak hardness is located at the cut edge (zero on the horizontal axis).

\subsection{Conclusion}

A best effort study of the fatigue life of abrasive water-jet cut titanium alloys was undertaken as part of TAP 09-02. Fatigue life demonstrated a distinct dependence on the quality level of the specimen. A baseline specimen prepared via a traditional machining process demonstrated superior fatigue life when compared to traditional AWJ cut specimens without surface conditioning after cutting. AWJ cut specimens that had undergone a post cut girt blasting, demonstrated a dramatic increase in fatigue life far exceeding the original fatigue life of the AWJ cut specimens. Unfortunately not enough data was obtained to related post cut blasted specimens with the baseline machined condition, but initial results obtained as part of this study look promising.

As a continuation of previous work of the OMAX Corporation an analysis of near surface hardness of laser cut titanium was performed. The comparative analysis between abrasive water jet cut specimens with both laser and wire EDM showed that the AWJ and laser cutting methods led to significantly less near surface hardening when compared with wire EDM at the same feed rates. 


\section{Appendix A}

\begin{tabular}{|c|c|c|c|c|c|c|c|c|c|}
\hline Sample ID & Date & Thickness & Width & $\begin{array}{l}\max \\
\text { load } \\
\text { kips }\end{array}$ & \begin{tabular}{|l|} 
MIN \\
LOAD \\
kips
\end{tabular} & $\begin{array}{l}\text { SETPOINT } \\
\text { kips }\end{array}$ & AMPLITUDE & Ksi & $\begin{array}{l}\text { cycles } \\
\text { to } \\
\text { failure }\end{array}$ \\
\hline & & & & \begin{tabular}{|l|}
0.0 \\
\end{tabular} & 0.00 & 0.00 & 0.00 & & \\
\hline TiMS125-1 & $3 / 12 / 2009$ & 0.12745 & 1.8410 & 16.4 & -0.33 & 8.05 & 8.38 & 70 & 348,057 \\
\hline TiMS125-2 & & & & 0.0 & 0.00 & 0.00 & 0.00 & & \\
\hline TiMS125-3 & & & & 0.0 & 0.00 & 0.00 & 0.00 & & \\
\hline \multirow[t]{2}{*}{ TiMS125-4 } & & & & 0.0 & 0.00 & 0.00 & 0.00 & & \\
\hline & & & & 0.0 & 0.00 & 0.00 & 0.00 & & \\
\hline TiAS125-1 & 3/9/2009 & 0.12715 & 1.7985 & 16.0 & -0.32 & 7.84 & 8.16 & 70 & $1,000,000$ \\
\hline TiAS125-2 & & & & 0.0 & 0.00 & 0.00 & 0.00 & & \\
\hline TiAS125-3 & & & & 0.0 & 0.00 & 0.00 & 0.00 & & \\
\hline \multirow[t]{2}{*}{ TiAS125-4 } & & & & 0.0 & 0.00 & 0.00 & 0.00 & & \\
\hline & & & & 0.0 & 0.00 & 0.00 & 0.00 & & \\
\hline TiAQ180-1 & $12 / 19 / 2008$ & 0.13040 & 1.8080 & 16.5 & -0.33 & 8.09 & 8.42 & 70 & 25,119 \\
\hline TiAQ180-2 & \begin{tabular}{|l|}
$12 / 19 / 2008$ \\
\end{tabular} & 0.13030 & 1.8050 & 16.5 & -0.33 & 8.07 & 8.40 & 70 & 35,047 \\
\hline TiAQ180-3 & $12 / 22 / 2008$ & 0.13040 & 1.8045 & 16.5 & -0.33 & 8.07 & 8.40 & 70 & 22,899 \\
\hline \multirow[t]{2}{*}{ TiAQ180-4 } & & & & 0.0 & 0.00 & 0.00 & 0.00 & & \\
\hline & & & & 0.0 & 0.00 & 0.00 & 0.00 & & \\
\hline TiAQ380-1 & \begin{tabular}{|l|}
$11 / 10 / 2008$ \\
\end{tabular} & 0.12920 & 1.8025 & 16.3 & -0.33 & 7.99 & 8.31 & 70 & 51,432 \\
\hline TiAQ380-2 & \begin{tabular}{|l|}
$12 / 1 / 2008$ \\
\end{tabular} & 0.12925 & 1.8015 & 16.3 & -0.33 & 7.99 & 8.31 & 70 & 55,988 \\
\hline TiAQ380-3 & $12 / 10 / 2008$ & 0.12900 & 1.8020 & 16.3 & -0.33 & 7.97 & 8.30 & 70 & 62,631 \\
\hline TiAQ380-4 & & & & 0.0 & 0.00 & 0.00 & 0.00 & 70 & \\
\hline & & & & 0.0 & 0.00 & 0.00 & 0.00 & & \\
\hline TiAQ580-1 & $11 / 19 / 2008$ & 0.12870 & 1.8005 & 16.2 & -0.32 & 7.95 & 8.27 & 70 & 50,930 \\
\hline TiAQ580-2 & \begin{tabular}{|l|}
$12 / 3 / 2008$ \\
\end{tabular} & 0.12870 & 1.8000 & 16.2 & -0.32 & 7.95 & 8.27 & 70 & 50,337 \\
\hline TiAQ580-3 & $12 / 15 / 2008$ & 0.12865 & 1.7950 & 16.2 & -0.32 & 7.92 & 8.24 & 70 & 63,336 \\
\hline TiAQ580-4 & & & & 0.0 & 0.00 & 0.00 & 0.00 & 70 & \\
\hline & & & & 0.0 & 0.00 & 0.00 & 0.00 & & \\
\hline TiAQ1220-1 & \begin{tabular}{|c|}
$1 / 19 / 2008$ \\
\end{tabular} & 0.12715 & 1.8065 & 16.1 & -0.32 & 7.88 & 8.20 & 70 & 22,160 \\
\hline TiAQ1220-2 & \begin{tabular}{|l}
$12 / 2 / 2008$ \\
\end{tabular} & 0.12730 & 1.8055 & 16.1 & -0.32 & 7.88 & 8.21 & 70 & 11,593 \\
\hline TiAQ1220-3 & $12 / 10 / 2008$ & 0.12760 & 1.8035 & 16.1 & -0.32 & 7.89 & 8.22 & 70 & 17,715 \\
\hline TiAQ1220-4 & & & & 0.0 & 0.00 & 0.00 & 0.00 & 70 & \\
\hline & & & & 0.0 & 0.00 & 0.00 & 0.00 & & \\
\hline TiAQ3220-1 & $11 / 10 / 2008$ & 0.12750 & 1.8020 & 16.1 & -0.32 & 7.88 & 8.20 & 70 & 27,512 \\
\hline TiAQ3220-2 & $12 / 10 / 2008$ & 0.12750 & 1.8025 & 16.1 & -0.32 & 7.88 & 8.20 & 70 & 26,561 \\
\hline TiAQ3220-3 & $12 / 16 / 2008$ & 0.12750 & 1.8015 & 16.1 & -0.32 & 7.88 & 8.20 & 70 & 36,640 \\
\hline TiAQ3220-4 & & & & 0.0 & 0.00 & 0.00 & 0.00 & 70 & \\
\hline & & & & 0.0 & 0.00 & 0.00 & 0.00 & 70 & \\
\hline TiAQ5220-1 & \begin{tabular}{|l|}
$11 / 18 / 2008$ \\
\end{tabular} & 0.12515 & 1.8000 & 15.8 & -0.32 & 7.73 & 8.04 & 70 & 39,924 \\
\hline TiAQ5220-2 & $12 / 9 / 2008$ & 0.12510 & 1.8000 & 15.8 & -0.32 & 7.72 & 8.04 & 70 & 69,731 \\
\hline TiAQ5220-3 & $12 / 17 / 2008$ & 0.12530 & 1.8000 & 15.8 & -0.32 & 7.74 & 8.05 & 70 & 56,233 \\
\hline TiAQ5220-4 & & & & 0.0 & 0.00 & 0.00 & 0.00 & 70 & \\
\hline & & & & 0.0 & 0.00 & 0.00 & 0.00 & & \\
\hline TiAQ180G-1 & & & & 0.0 & 0.00 & 0.00 & 0.00 & 70 & \\
\hline TiAQ180G-2 & & & & 0.0 & 0.00 & 0.00 & 0.00 & 70 & \\
\hline TiAQ180G-3 & & & & 0.0 & 0.00 & 0.00 & 0.00 & 70 & \\
\hline TiAQ180G-4 & & & & 0.0 & 0.00 & 0.00 & 0.00 & 70 & \\
\hline & & & & 0.0 & 0.00 & 0.00 & 0.00 & 70 & \\
\hline TiAQ5220G-1 & & & & 0.0 & 0.00 & 0.00 & 0.00 & 70 & \\
\hline TiAQ5220G-2 & $5 / 20 / 2009$ & 0.12480 & 1.7995 & 15.7 & -0.31 & 7.70 & 8.02 & 70 & 194665 \\
\hline TiAQ5220G-3 & & & & 0.0 & 0.00 & 0.00 & 0.00 & & \\
\hline TiAQ5220G-4 & & & & 0.0 & 0.00 & 0.00 & 0.00 & & \\
\hline & & & & 0.0 & 0.00 & 0.00 & 0.00 & & \\
\hline TiAQ480-1 & & & & 0.0 & 0.00 & 0.00 & 0.00 & 70 & \\
\hline TiAQ480-2 & & & & 0.0 & 0.00 & 0.00 & 0.00 & 70 & \\
\hline TiAQ480-3 & & & & 0.0 & 0.00 & 0.00 & 0.00 & 70 & \\
\hline TiAQ480-4 & & & & 0.0 & 0.00 & 0.00 & 0.00 & 70 & \\
\hline & & & & 0.0 & 0.00 & 0.00 & 0.00 & & \\
\hline TiAQ4120-1 & & & & 0.0 & 0.00 & 0.00 & 0.00 & 70 & \\
\hline TiAQ4120-2 & & & & 0.0 & 0.00 & 0.00 & 0.00 & 70 & \\
\hline TiAQ4120-3 & & & & 0.0 & 0.00 & 0.00 & 0.00 & 70 & \\
\hline TiAQ4120-4 & & & & 0.0 & 0.00 & 0.00 & 0.00 & 70 & \\
\hline & & & & 0.0 & 0.00 & 0.00 & 0.00 & & \\
\hline TiAQ5120-1 & & & & 0.0 & 0.00 & 0.00 & 0.00 & 70 & \\
\hline TiAQ5120-2 & & & & 0.0 & 0.00 & 0.00 & 0.00 & 70 & \\
\hline TiAQ5120-3 & & & & 0.0 & 0.00 & 0.00 & 0.00 & 70 & \\
\hline TiAQ5120-4 & & & & 0.0 & 0.00 & 0.00 & 0.00 & 70 & \\
\hline & & & & 0.0 & 0.00 & 0.00 & 0.00 & & \\
\hline TiAQ5320-1 & $12 / 19 / 2008$ & 0.1281 & 1.7995 & 16.1 & -0.32 & 7.91 & 8.23 & 70 & 47890 \\
\hline TiAQ5320-2 & $12 / 19 / 2008$ & 0.1281 & 1.7995 & 16.1 & -0.32 & 7.91 & 8.23 & 70 & 55766 \\
\hline TiAQ5320-2 set 2 & $12 / 22 / 2008$ & 0.1269 & 1.797 & 16.0 & -0.32 & 7.82 & 8.14 & 70 & 62397 \\
\hline TiAQ5320-3 & & & & 0.0 & 0.00 & 0.00 & 0.00 & 70 & \\
\hline TiAQ5320-4 & & & & 0.0 & 0.00 & 0.00 & 0.00 & 70 & \\
\hline & & & & 0.0 & 0.00 & 0.00 & 0.00 & & \\
\hline TiAQ5120G-1 & $11 / 7 / 2008$ & 0.1275 & 1.797 & 16.0 & -0.32 & 7.86 & 8.18 & 70 & 56,689 \\
\hline TiAQ5120G-2 & & & & 0.0 & 0.00 & 0.00 & 0.00 & 70 & \\
\hline TiAQ5120G-3 & & & & 0.0 & 0.00 & 0.00 & 0.00 & 70 & \\
\hline TiAQ5120G-4 & & & & 0.0 & 0.00 & 0.00 & 0.00 & 70 & \\
\hline & & & & & & & & & \\
\hline TiAQ4120G-1 & $2 / 13 / 2009$ & 0.12735 & 1.7935 & 16.0 & \begin{tabular}{|c|}
-0.32 \\
\end{tabular} & 7.83 & 8.15 & 70 & $1,000,000$ \\
\hline TiAQ4120G-2 & & & & 0.0 & 0.00 & 0.00 & 0.00 & 70 & \\
\hline TiAQ4120G-3 & & & & 0.0 & 0.00 & 0.00 & 0.00 & 70 & \\
\hline TiAQ4120G-4 & & & & 0.0 & 0.00 & 0.00 & 0.00 & 70 & \\
\hline
\end{tabular}


Prepared for the OMAX Corporation, Kent

Washington under TAP agreement 09-02

with the U.S. Department of Energy Contract

DE-AC05-76RL01830

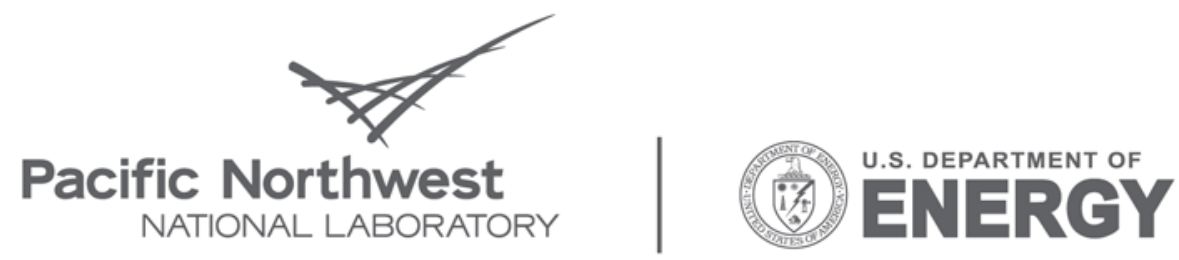

Proudly Operated by Battelle Since 1965

902 Battelle Boulevard

P.O. Box 999

Richland, WA 99352

1-888-375-PNNL (7665)

www.pnl.gov 